\title{
Hydrodynamic aspect of caves
}

\author{
Mitja Prelovšek ${ }^{1}$, Janez Turk², Franci Gabrovšek ${ }^{3}$
}

\begin{abstract}
:
Prelovšek M., Turk J. and Gabrovšek F. 2008. Hydrodynamic aspect of caves. International Journal of Speleology, 37 (1), 11-26. Bologna (Italy). ISSN 0392-6672.

From a hydrological point of view, active caves are a series of connected conduits which drain water through an aquifer. Water tends to choose the easiest way through the system but different geological and morphological barriers act as flow restrictions. The number and characteristics of restrictions depends on the particular speleogenetic environment, which is a function of geological, geomorphological, climatological and hydrological settings. Such a variety and heterogeneity of underground systems has presented a challenge for human understanding for many centuries. Access to many underground passages, theoretical knowledge and recent methods (modeling, water pressure-resistant dataloggers, precise sensors etc.) give us the opportunity to get better insight into the hydrodynamic aspect of caves.

In our work we tried to approach underground hydrodynamics from both theoretical and practical points of view. We present some theoretical background of open surface and pressurized flow in underground rivers and present results of some possible scenarios. Moreover, two case studies from the Ljubljanica river basin are presented in more detail: the cave system between Planinsko polje and Ljubljansko barje, and the cave system between Bloško polje and Cerkniško polje. The approach and methodology in each case is somewhat different, as the aims were different at the beginning of exploration. However, they both deal with temporal and spatial hydrodynamics of underground waters. In the case of Bloško polje-Cerkniško polje system we also explain the feedback loop between hydrodynamics and Holocene speleogenesis. Keywords: karst hydrology, cave hydrodynamics, Ljubljanica river, Križna jama, Slovenia
\end{abstract}

Received 23 August 2007; Revised 3 October 2007; Accepted 5 November 2007

\section{INTRODUCTION}

Karst aquifers are dominated by a network of connected conduits developed within a fractured and/or porous rock. Flow of groundwater in karst is complex, and extreme variation of conductivities enables practically all natural flow regimes. Interaction between conduits and the adjacent fracture-matrix system plays an important role in karst hydrology. Nevertheless in conduit dominated aquifers with low bedrock porosity and conductivity, such exchange can be neglected when discussing short term flood response of the system (Peterson and Wicks, 2005; Jeannin, 2001). Our focus is flow in large

1 Karst Research Institute SRC SASA, Titov trg 2, SI-6230

Postojna, Slovenia mitja.prelovsek@zrc-sazu.si

2 Karst Research Institute SRC SASA, Titov trg 2, SI-6230

Postojna, Slovenia. janez.turk@zrc-sazu.si

3 Karst Research Institute SRC SASA, Titov trg 2, SI-6230

Postojna, Slovenia. gabrovsek@zrc-sazu.si underground channels (=caves) in the epiphreatic zone of a karst aquifer, in other words the flow of underground rivers.

We begin with basic principles and equations of flow in open and pressurized channels. These can be used to model underground flow and interpret the data recorded from different measurements. These measurements can sometimes include only a few accessible points within the hydrological system. Such an example is presented by case study 1 , where results of long term monitoring by data loggers (TD Divers) are presented. Other underground rivers are accessible along longer segments. Such a system is presented in the second case study where long and easily accessible epiphreatic water flow allows the mapping and measurement of water properties at many locations. Since hydraulic permeability is not a constant in long terms, some measurements on time variations in underground hydraulic properties can be done. 


\section{Theoretical background of flow in underground rivers}

Water can enter caves as an allogenic concentrated input or autogenic either discrete or diffuse recharge through different systems of fissures, fractures and conduits. Due to its specific evolution, the geometry of karst channels shows extreme variations along a single water course. Often the channel cross-sections on the same flow path change by more than an order of magnitude. Variability of geometry and temporal variability of recharge create conditions for free surface and/or pressurized flow, with frequent spatial and temporal transitions between both regimes.

Flow of water is governed by the Navier-Stokes equation, which is in principle the application of Newton's second law. It states that the change of momentum in infinitesimal fluid volume is the sum of all forces acting on it. These forces include dissipative viscous forces, changes in pressure, gravity etc. For most practical uses the equation is too complex to solve. We do not even know if the solution in three dimensions always exists. Various CFD (Computational Fluid Dynamics) software packages make it possible to seek special solutions of the Navier-Stokes equation. Hauns et al. (1998) presented a model of flow and transport based on a CFD solution of Navier-Stokes equation for a karst channel.

Still, for most applications we look for a simplified version of Navier-Stokes equation which suits the particular problem.

\section{Saint-Venant equation}

For free surface flow in rivers, surface and underground, the simplification is the Saint-Venant equation. Instead of looking at an infinitesimal fluid parcel, the equation describes mass and momentum conservation along the whole depth profile of an infinitesimally long stream section. The flow is thus considered as one-dimensional. Further simplifying assumptions include small streamline curvature, no vertical acceleration and small bed slope (i.e. ). All friction forces are lumped in an empirical relation known as Manning's equation:

$$
j=\frac{n^{2} Q^{2}}{A^{2} R^{4 / 3}}
$$

$Q$ is the flow rate, $n$ is Manning's roughness coefficient which we discuss latter on, $A$ is the wetted area and $R$ hydraulic radius, the ratio between the wetted area and wetted perimeter. In fact, as we shall see, Eq. 1 is a steady state approximation of Saint-Venant equation. It has recently been proven theoretically (Gioia and Bombardelli, 2002).

Mass conservation in a stream section yields:

$$
b(h) \frac{\partial h}{\partial t}+\frac{\partial Q}{\partial x}=q
$$

where $b(h)$ is the flow width at the top, $h$ the flow depth and $q$ is the density of lateral inflow. Applying $Q=A \cdot v$, where $v$ is an average velocity across the whole depth profile, the equation becomes:

$$
b(h) \frac{\partial h}{\partial t}+A \frac{\partial v}{\partial x}+v \frac{\partial A}{\partial x}=q
$$

A bit more complicated is the conservation of momentum. Its rate of change is equal to the forces acting on it. Generally we expect three types of forces acting on a fluid parcel w: gravitational force, force due to the static pressure change, and friction forces. For small channel slope $\sin (\Theta)=\Theta=i$, and the conservation of momentum can be written as:

$$
\frac{\partial v}{d t}+v \frac{\partial v}{\partial x}+g \frac{\partial h}{\partial x}=g(i-j)+q v_{x}
$$

$V_{x}$ is the component of lateral flow velocity along he direction of flow. Eqs. 3 and 4 give a complete set of Saint Venant equations. Further details on the equation can be found in classical textbooks (Chow, 1988; Dingman, 2002). There is no analytical solution for the general Saint-Venant equation, however many numerical approaches exist.

Under certain conditions some terms in Eq. 4 can be neglected. A so-called kinematic approximation neglects pressure forces and acceleration terms. In a case without lateral input (i.e. $q=0$ ) this means that $i-j=0$, i.e. the friction slope equals the bed slope which means that momentum part is simply given by Manning's equation (see also Eq.1):

$$
Q=\frac{1}{n} A R^{2 / 3} i^{1 / 2}
$$

For non-steady flow the equation together with mass conservation (Eq. 2) gives a kinematic wave approximation:

$$
\frac{\partial h}{\partial t}+\frac{3 U_{u}}{2} \frac{\partial h}{\partial x}=0
$$

For a uniform channel with no lateral inputs the solution of Eq.6 is a flood-wave which travels downstream unaltered with a velocity $3 U_{u} / 2$, where $U_{u}$ is velocity obtained from Mannings equation (Eq.1), taking $Q=A \cdot U_{u}$.

A closer approximation is a ConvectionDiffusionEquation which keeps the pressure forces $g \cdot \partial h / \partial x$ but neglects the inertial force. The result is a flood-wave with declining crest as it moves downstream. The equation also accounts for the backwater effects. 
The most radical approximation of the Saint-Venant equation is a steady state one. All that is left from mass and momentum conservation is the Manning's equation (Eq. 5.)

\section{Steady state equations for open channel and full pipe flow}

Underground rivers experience transitions to pressurized (full pipe) flow. Manning's equation can be applied also for pressurized flow, but more often the Darcy-Weisbach equation is used, where the friction head loss per unit length is given by:

$$
j=f \frac{Q^{2}}{2 \cdot D \cdot A}
$$

$D$ is hydraulic radius, g gravitational acceleration, and $f$ the friction factor.

As a general rule, steady state relations for the head loss can be written as a power law of the type $j=K \cdot Q^{m}$ (Larock et al., 2000), where $K$ and $m$ change depending on the particular equation used (e.g. Manning, DarcyWeisbach, Hazen Williams).

Rozos and Koutsoyiannis (2006) introduced a Manning type equation which accounts for the steady state free surface and pressurized flow:

$$
Q=\frac{\mathrm{b}}{n}\left(\frac{h}{D}\right)^{\mathrm{a}} i^{1 / 2}
$$

$D$ is the height of the conduit. Parameters $\alpha$ and $\beta$ are obtained numerically and depend on the geometry of cross-section and hydraulic radius.

Jeannin (2001) successfully applied the DarcyWeisbach equation to model flow in the lower part of the Hölloch system in Switzerland.

\section{Friction factors}

Manning's $n$ for "streams with no vegetation with steep banks and bottom covered with cobbles and boulders" has values between 0.03 and 0.07 (Dingman, 2002). Wall roughness in karst conduits shows large variability. The friction factor $f$ in the Darcy-Weisbach equation is discussed by several authors. Gale (1984) obtained hydraulic conditions and parameters based on the analysis of rock dissolution forms and sediments. From scallop distributions he obtained a friction factor of the scalloped walls between 0.04 to 0.13 from different locations. From studies of fluidtransported sediments in Fissure Cave (U.K.) he obtained $f=0.17$.

Besides wall friction, other sources of head loss are present along the course of a river. These include entrance losses, where water enters conduit from a large pool (reservoir), sudden and gradual expansion and contraction losses, where cross-section changes (Springer, 2004), losses at bends etc. These losses are generally written in the form $K\left(v^{2} / 2 g\right)$.

\section{Use of SWMM to model the hydrodynamics in epiphreatic zone}

To demonstrate some of the theory, we present a few simple examples where listed formulae come into action. To this extent we will apply the Storm Water Management Model (SWMM) which is primarily designed to simulate flow and transport in sewer systems (Rossman, 2007). SWMM has been successfully used for karst drainage systems where the conduit geometry is well known (Campbell and Sullivan, 2002; Peterson and Wicks, 2006). Here we use it "uncritically" to present a few scenarios which demonstrate some of the typical behavior expected in karst systems.

Therearemanyexampleswhereariversinks underground into large conduits and runs into a restriction. A modeling scenario for such case is presented in Fig. 1a.

The input into the system increases slowly enough to meet steady state conditions.

Fig. 1b shows the level of the water at the entrance of the restriction when depending on the flow rate. The conduit representing restriction is $2 \mathrm{~m}$ high and $5 \mathrm{~m}$ wide. Manning's roughness coefficient is 0.05 .

Initially the level rises following the relation for open channels (see Eq.5). When the conduit becomes pressurized the level increases with a higher power of flow, normally between 1 and 2. Gabrovšek and Peric (2006) used similar models to interpret data obtained by continuous monitoring of flow and water levels in the caves.

The details of the transition from free surface to pressurized flow becomes complex and is beyond the scope of this paper and probably irrelevant for karst conduits.

The course of an underground river can include many restrictions and large channels or chambers that act as storage reservoirs. A simple scenario with a series of chambers (= storage reservoirs) and conduits is shown in Fig. 2. All conduits have length of $200 \mathrm{~m}$, they are $5 \mathrm{~m}$ wide. Their height is 4,2 and $1 \mathrm{~m}$ from upper to lower channel, respectively. A triangular flow hydrogram as shown on Fig. $2 b$ is introduced to the system. Levels $h_{1}$, $h_{2}, h_{3}$ in the reservoir are initially linked to the free surface levels in the conduits, but rise steeply once the conduits become pressurized. Similar systems of reservoir and

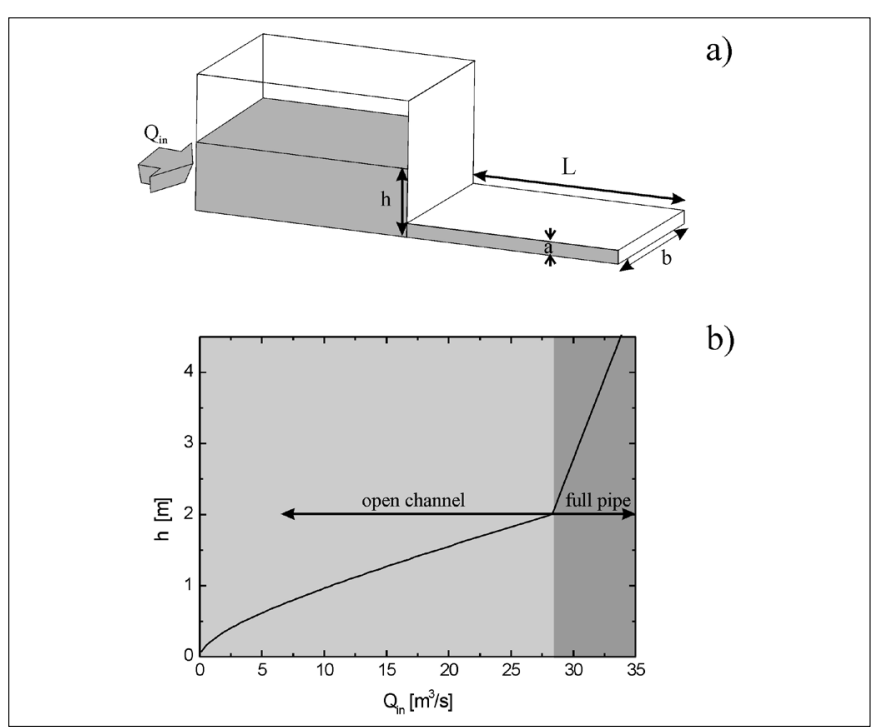

Fig. 1. a) Model of large conduit ending with restriction. b) Dependence of a level at the entrance of restriction on recharge. 


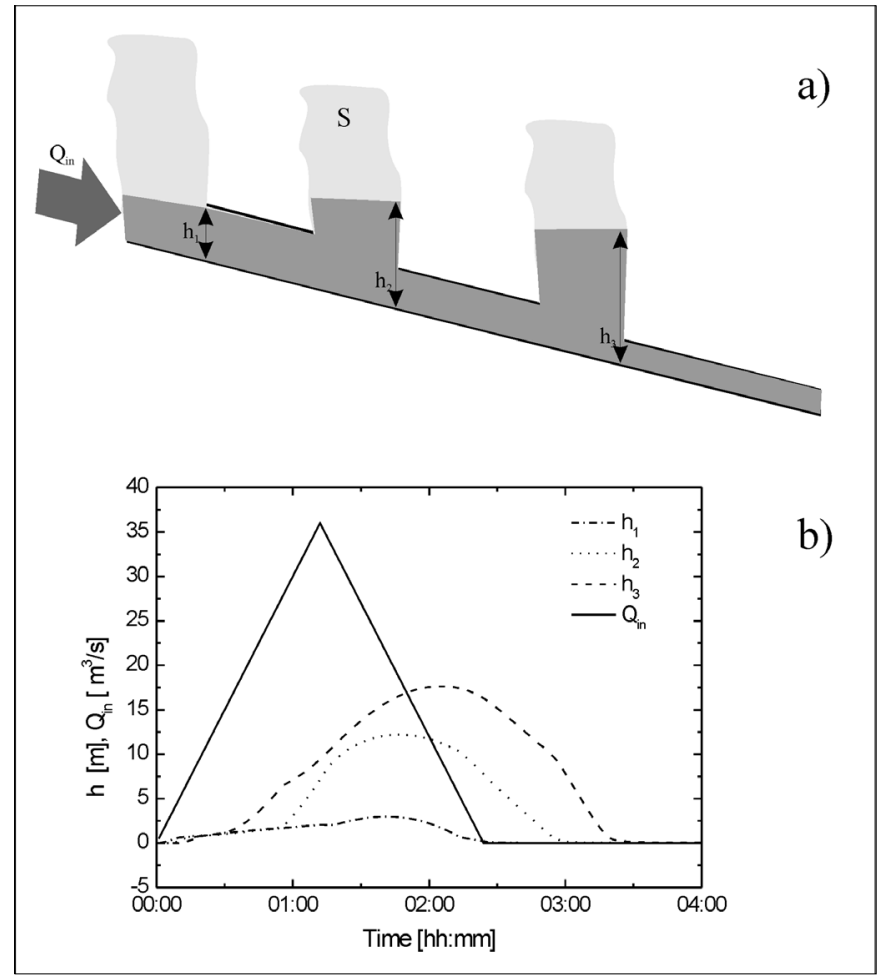

Fig. 2. Model of a series of chambers (storage reservoirs) with connecting conduits. b) Flow hydrogram at the entrance of the system and level hydrograms in the chambers.

restriction were discussed by Halihan and Wicks (1998) who used it to model the storm response of cave system in Missouri, USA.

\section{Time variation of hydraulic properties}

Hydraulic properties of karst conduits change in time. Short term changes are consequence of breakdown, sedimentation, and flotsam transport. These changes can occur within a very short time span, e.g. single flood event.

Long term changes are the consequence of dissolution and flowstone deposition processes. Such an example can be seen in Križna jama where a series of flowstone dams considerably changes the hydrodynamics of flow. The lakes behind the dams act as a series of storage reservoirs which dampens the flood response.

\section{CASE STUDY 1: HYDRODYNAMICS OF UNDERGROUND WATER FLOW BETWEEN PLANINSKO POLJE AND LJUBLJANICA SPRINGS}

\section{Introduction}

Several methods were used to assume hydrodynamic of underground flow in karst areas. We studied characteristics and behavior of underground flow according to two parameters: the water level in caves and discharge of surface river as a simplified source of input. For more detailed interpretation hydraulic gradients between studied areas should also be taken into consideration.

We observed the response of epiphreatic zone on defined flood pulses as a consequence of rain events, to evaluate the hydrodynamics of the system.

\section{Description of the system}

We monitored water levels (autumn 2006 - winter 2007) in selected caves in the Ljubljanica catchment area (Fig. 3). Ljubljanica emerges in many springs at the border of karstic Jurassic limestone and nonkarstic Quaternary sediments, which fill the tectonic basin of Ljubljansko barje (Ljubljana marsh; Pleničar et al., 1970). Springs collect waters from the extreme NW part of the Dinaric karst (known as "classical karst"). The estimated area of the Ljubljanica drainage basin is $1109 \mathrm{~km}^{2}$ (Šušteršič, 2000). It is one of the most complex in the Dinaric karst.

Because of the complexity of the system, we focused on one area, which covers Planinsko polje (Planina polje) with Unica River, Logaški ravnik (Logatec "leveled surface") with selected caves, where water levels were measured, and a part of Cerkniško polje (Cerknica polje) with its seasonal lake.

Planinsko polje is typical overflow polje with an area of $16 \mathrm{~km}^{2}$ (Gospodarič \& Habič, 1976). Main karstic springs are situated at the southern margin of the polje. Unica spring is directly fed by underground Pivka and Rak Rivers (Kogovšek, 2004).

The Unica River sinks in swallow holes, which are situated along the river bed in the eastern and northern margin of the polje (Fig. 3). Swallow hole activity is dependent on hydrological conditions, therefore all swallow holes are not active permanently. Those located in the eastern margin of the polje are active even during low discharge, but those in the northern part are only active during medium and high discharge (Šušteršič, 1982). The capacity of the swallow holes is too small to transmit all water during high discharge and consequently the polje becomes flooded. Flood water can rise as much as 10 meters above the bottom of the polje (Gospodarič \& Habič, 1976).

Logaški ravnik is built of Cretaceous limestone. Thickness of the unsaturated zone varies from a few 10 s to more than 100 meters. This relatively high thickness is a reason why the underground flow was measurable a only in few caves in this area: in Mačkovica and Logarček caves in the direct vicinity of the eastern margin of the polje, in Vranja jama and Najdena jama (Fig. 3, cave No. 1) caves just near the northern margin of the polje and in Gradišnica cave (Fig. 3, cave No. 2). In the year 2002 underground water was reached also in Gašpinova jama (Gašpin's Cave; Fig. 3, cave No. 3) and in 2004 in Vetrovna jama (Fig. 3, cave No. 4) caves. The level of underground flow, which is an object of our discussion, was measured in the last four mentioned caves, shown in Fig. 3. These caves consist of large conduits, with diameters of a few to a few tens of meters. According to Bonacci (1987) such conduits represent around $90 \%$ of all cave passages and only a minor percent of conduits is inaccessible to humans. Because of the restrictions, connections between selected caves can not be proved physically. Restrictions have a significant role on epiphreatic zone flow and on hydraulic conditions of underground flow as discussed in the theoretical introduction. 


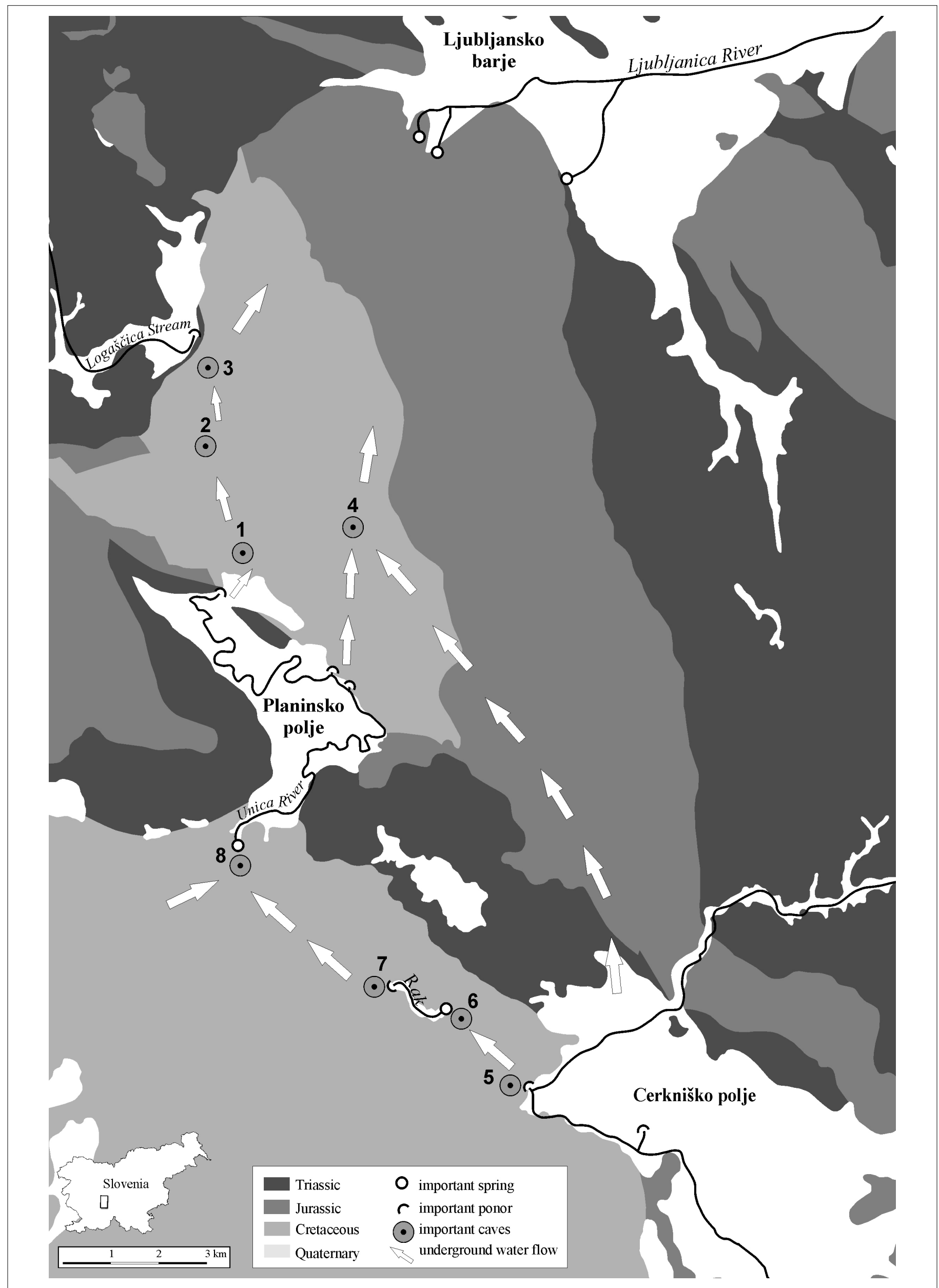

Fig. 3. Map of the study area. 


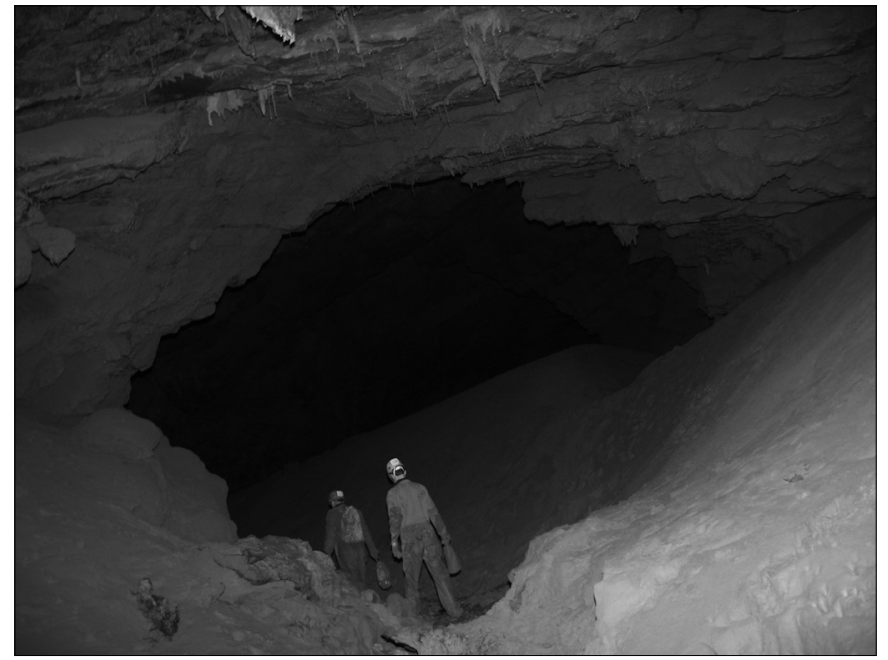

Fig. 4.Typical epiphreatic conduit in Gašpinova jama (Photo: Andrej Mihevc).

Cerkniško polje covers about $36 \mathrm{~km}^{2}$, during floods it alters to a spacious karst lake. The highest waters run off through the caves Mala and Velika Karlovica (Fig. 3, cave No. 5) and Zelške jame (Fig. 3, cave No. 6). Those waters feed the Rak River, which sinks underground into Tkalca jama (Fig. 3, cave No. 7). This underground stream finally joins the Pivka River and appears as Unica River at the entrance of Planinska jama (Planina Cave; Fig. 3, cave No. 8; Gospodarič \& Habič, 1976).

Especially at times of medium and low flow, waters sink in marginal and numerous ground swallow holes, the last ones are disposed in central polje's bottom. Lake water disappearing in swallow holes flows underground directly in direction of Ljubljanica springs (Gospodarič \& Habič, 1976).

\section{Measurements and methodology}

TD Divers produced by Van Essen were used to establish monitoring of underground flow. They measure water level and temperature. The sample interval may be set arbitrarily; in our case it is 15 or 30 minutes.

First results of continuous measurements in four selected caves are presented in this paper. Hydrodynamical characteristics of underground flow may be inferred by relations between water levels in discussed caves. To assess hydraulic conditions in the caves, relations between water levels in the caves and discharges of surface Unica, before it starts to sink in the swallow holes, were made in the same way that Gabrovšek \& Peric (2006) did for the Reka River system. Discharges of the surface Unica River were calculated using an unofficial stage - discharge curve, which was made by the Environmental Agency at the Ministry of the Environment and Spatial Planning of Slovenia. On its course over Planinsko polje, the Unica River "leaks" into many swallow holes, which do not feed the same cave systems. Despite this fact, water level in the caves is strongly correlated with discharge of the surface river, before it starts to sink underground. Real discharge through caves, where monitoring was established, is unknown and

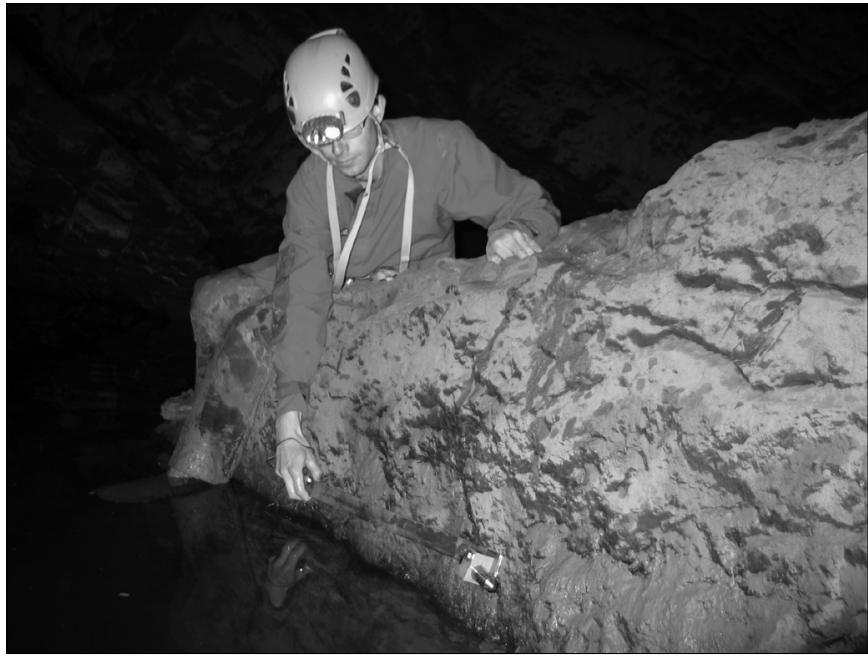

Fig. 5. Installation of TD Diver in Gradišnica at low water conditions. Water level rises even $50 \mathrm{~m}$ above TD Diver at high water conditions (Photo: Franci Gabrovšek).

impossible to measure. Mean Unica River discharge is around $21 \mathrm{~m}^{3} / \mathrm{s}$, the highest discharge is up to 80 $\mathrm{m}^{3} / \mathrm{s}$ (Gospodarič \& Habič, 1976). Flood pulses in our evaluation do not exceed $40 \mathrm{~m}^{3} / \mathrm{s}$.

We should take into consideration that all discharge - level plots are very approximate not only because of unknown real discharge through the caves, but also because of unknown travel time between two measuring points (discharge at the surface and water levels in caves). We joined maximal discharge of Unica with equivalent maximal water level in selected caves, to address the issue of time delay. It means that we consider the shortest travel time, which coincides with maximal discharge, as an average travel time of a selected flood pulse. In reality, the travel time depends on flow velocity, which is directly linked with discharge. Our simplifications offer some logical results, despite this simplification.

\section{Hydrodynamic characteristics in the cave system Najdena jama - Gradišnica - Gašpinova jama}

The nearest part of Najdena jama is situated only 150 meters from the Planinsko polje and siphon, where measurements are taken around $0.5 \mathrm{~km}$ from polje. It is undoubtedly fed by the Unica River, which sinks into swallow holes at the northern margin of the polje named "Pod stenami". The connection of underground waters from Najdena jama with the Gradišnica was assumed according to observed water levels in both caves (Gospodarič \& Habič, 1976). Also, our data prove that high water levels in Najdena jama, Gradišnica and Gašpinova jama caves are strongly related.

By comparing water levels, we noticed that the level rise in the Gradišnica and Gašpinova jama begins at a lower discharge level for the surface Unica River than the level in Najdena jama (November 2006 and January 2007 - Fig. 6a and c). Water in Najdena jama rises only about two meters at a Unica River discharge of $25 \mathrm{~m}^{3} / \mathrm{s}$. The reason is that discharge of the surface Unica is too low in such a case to reach the "Pod stenami" swallow holes. As shown in Fig. 6c, we may 
assume that Gradišnica and Gašpinova jama get some input from swallow holes, which do not feed Najdena jama. A small flood pulse in January 2007 caused an increase of Unica River discharge from 7 to $23 \mathrm{~m}^{3} / \mathrm{s}$. Fig. $6 c$ proves that in Najdena jama there was only a slight change in water level. On the contrary, water level in Gradišnica and Gašpinova jama increased by 11 meters. The shapes of the water level curves follow the curve of Unica River discharge with some time delay.

We should take into account also some unknown inflows inside the cave system. At least for Gašpinova jama, it is known that the underground Hotenka stream feeds it. It is an underground continuation of a brook, which sinks underground NW of Logatec. It is possible, that even the brook Logaščica contributes some water to Gašpinova jama. Even autogenic recharge during more intensive rain should not be neglected. Such secondary inputs may explain why flood pulses in Gašpinova jama usually slightly precede those in the cave Gradišnica (by around one hour). They could also explain a small flood event in November 2006 (Fig. 6a), when water in the Gradišnica and Gašpinova jama rose almost ten meters and there was no significant relation with Unica discharge.

The dependency between water levels (in the three discussed caves) and surface Unica discharge was used to assume hydraulic conditions in caves.

Two flood pulses (December 2006 and end of January 2007) were chosen to observe water level rise in the

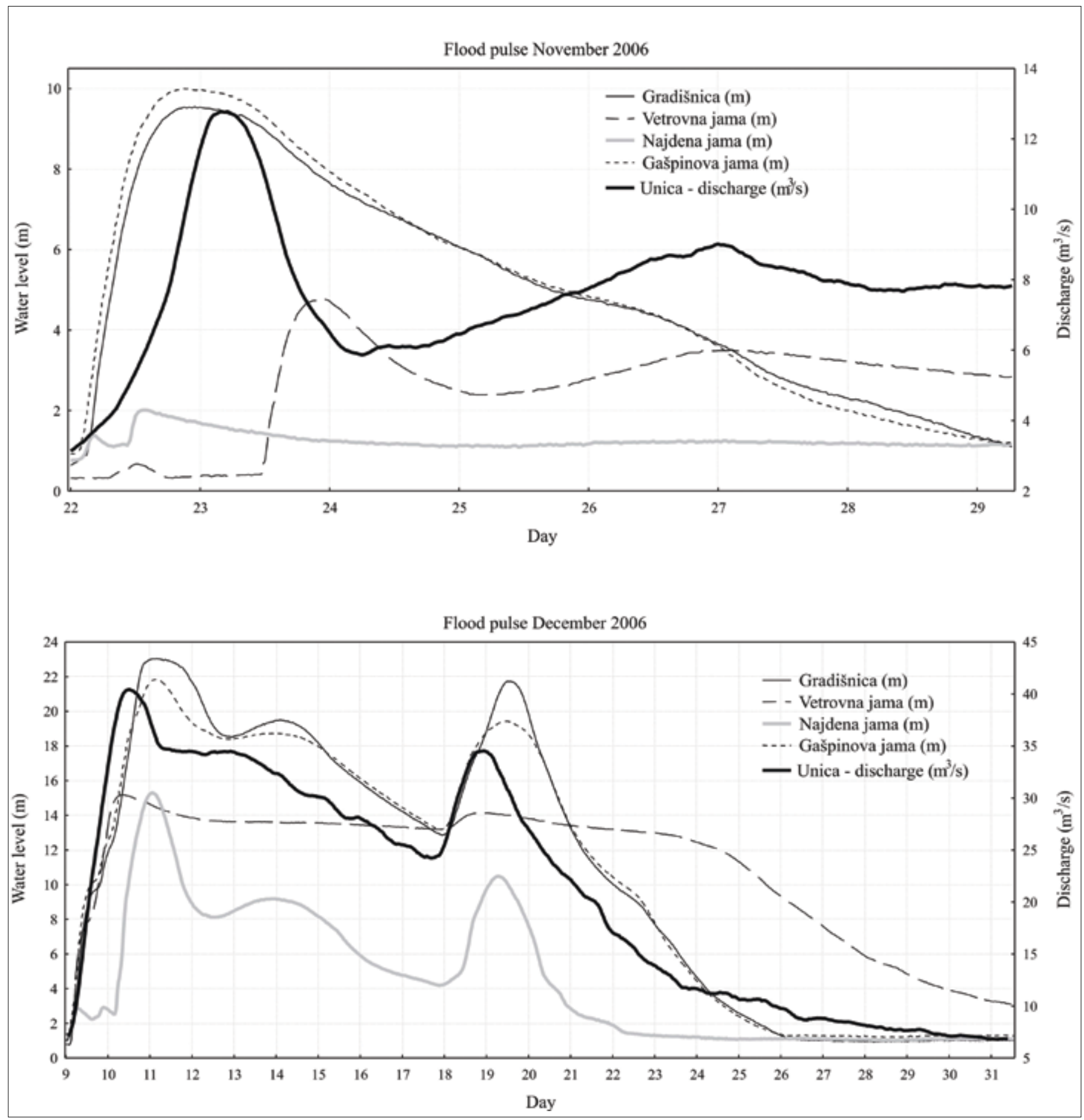

Fig. 6. Flood pulses in November 2006 (above) and in December 2006 (below) 


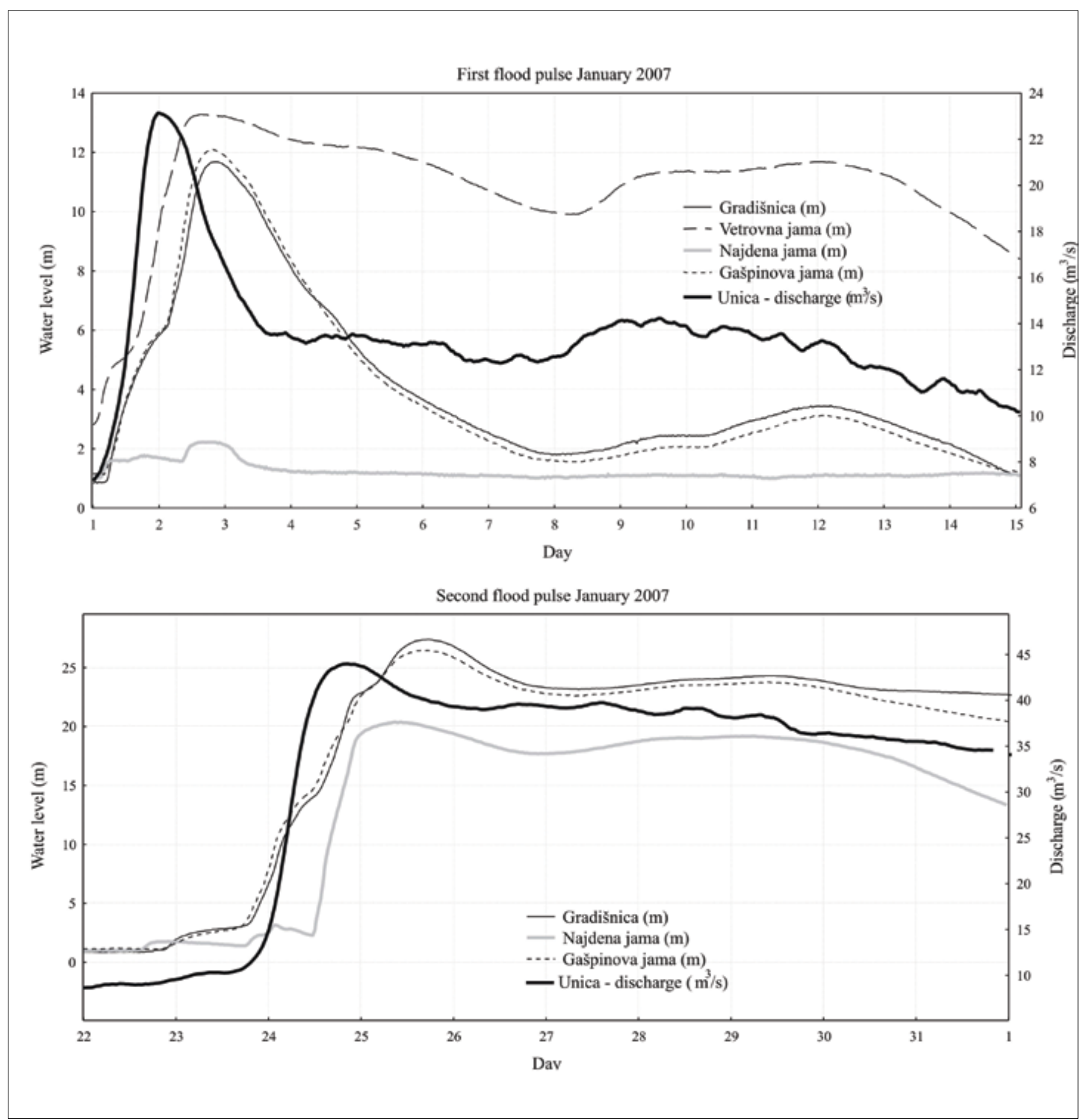

Fig. 6. Flood pulses in first half of January 2007 (above) and second half of January 2007 (below).

discussed caves. Unica discharge was rising relatively faster during flood pulse in December 2006, than in the end of January 2007. Maximum discharges were similar, approximately 41 and $44 \mathrm{~m}^{3} / \mathrm{s}$ (Fig.7).

According to relations between water levels in caves and Unica River discharge, response to two flood pulses was different in all three caves. The faster flood pulse in Najdena jama is reflected in rapid level rising from the beginning, while the water level reacted to the slower flood pulse with some time delay (Fig. 8).

Also in Gradišnica, the water level rose in a different way during the faster and slower flood pulses (Fig. 9). The water level rose for more than 20 meters in two days in both cases. After a rise of 22 meters, water started to overflow into Hoteje and Štirna shaft. From then on, the water level increased only gently although discharge increased by three times after the start of overflow.

A very similar relation between water level and discharge as in the Gradišnica, was also observed in Gašpinova jama.

Response to the faster flood pulse could be interpreted as a restriction and inability to transmit rapid inflowing water, and as faster transition from open channel to full pipe flow. But based upon the morphology of conduits in the studied caves, this explanation is excluded.

We interpret different responses as a consequence of splitting Unica recharge into different swallow holes. Swallow holes located in eastern margin of polje do not recharge Najdena jama. Faster surface flood pulse fed swallow holes in the eastern margin of the polje in 


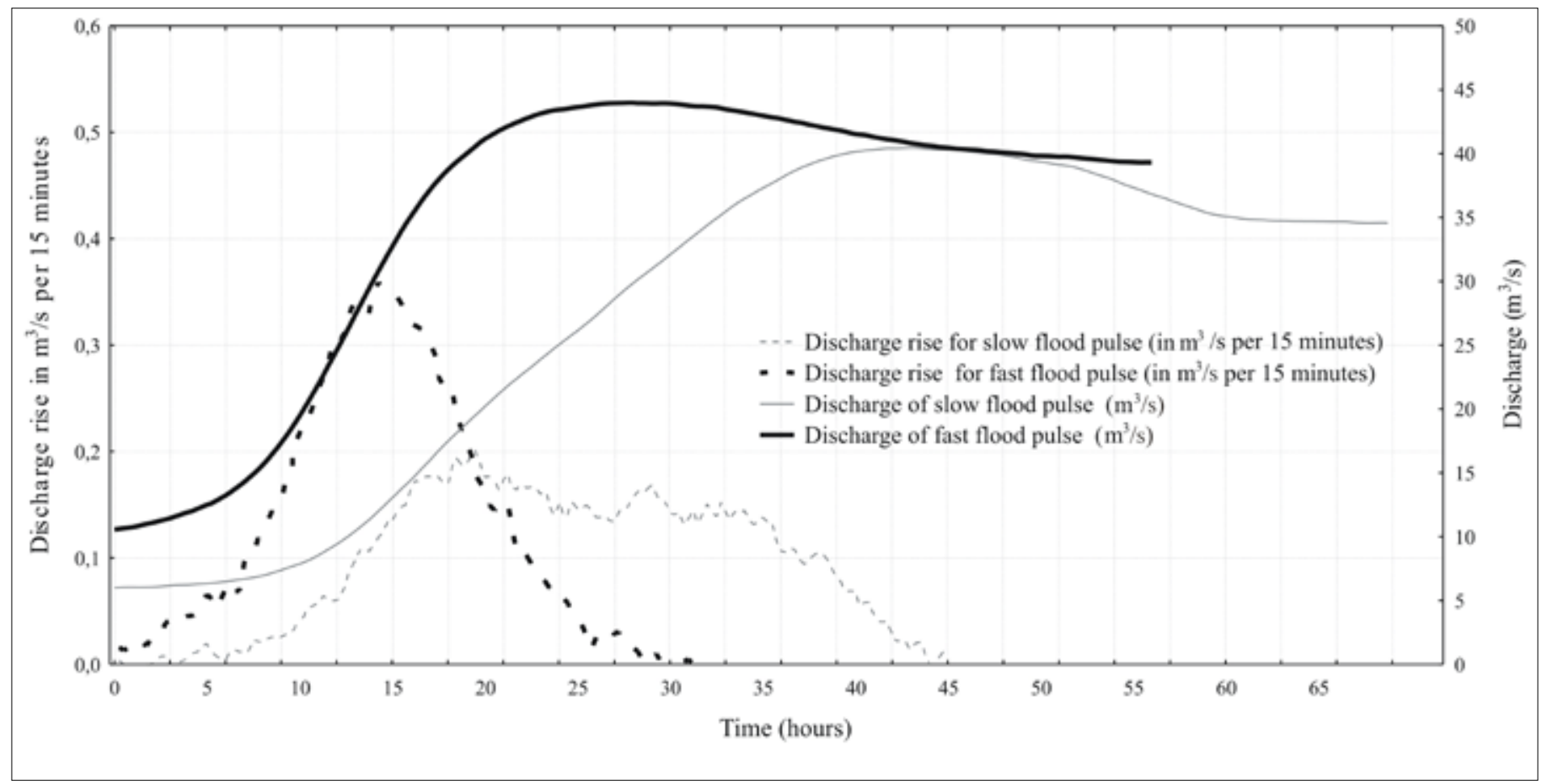

Fig. 7. Comparison of two flood pulses. Dotted curves correspond to velocity of discharge increasing during flood pulse. End of dotted curves at specific time coincides with maximal discharges of surface Unica River or maximum level of flood pulse (full line) in December 2006 and second half of January 2007.
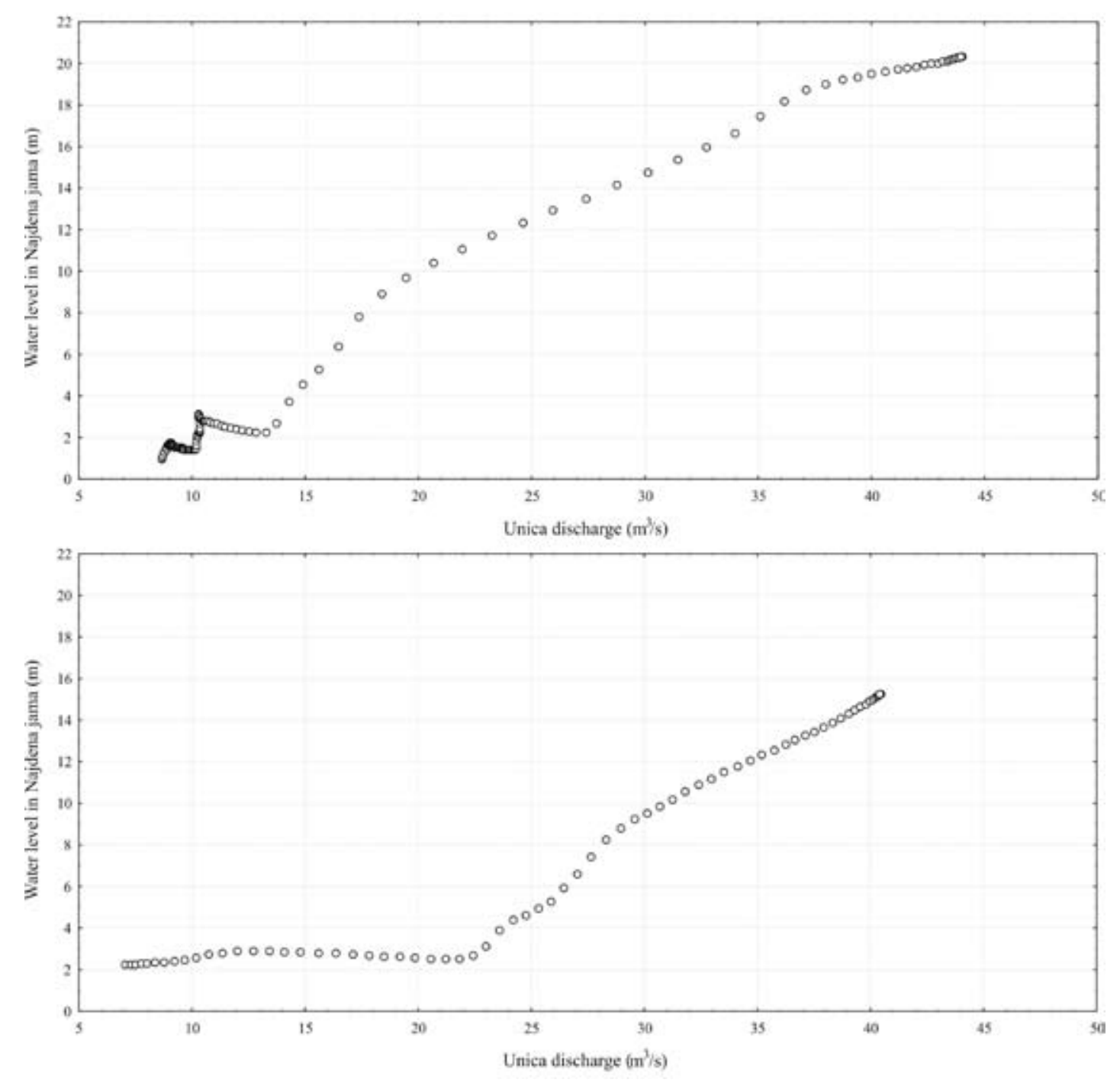

Fig. 8. Rapid event in Najdena jama (above), Slow event in Najdena jama (below). 

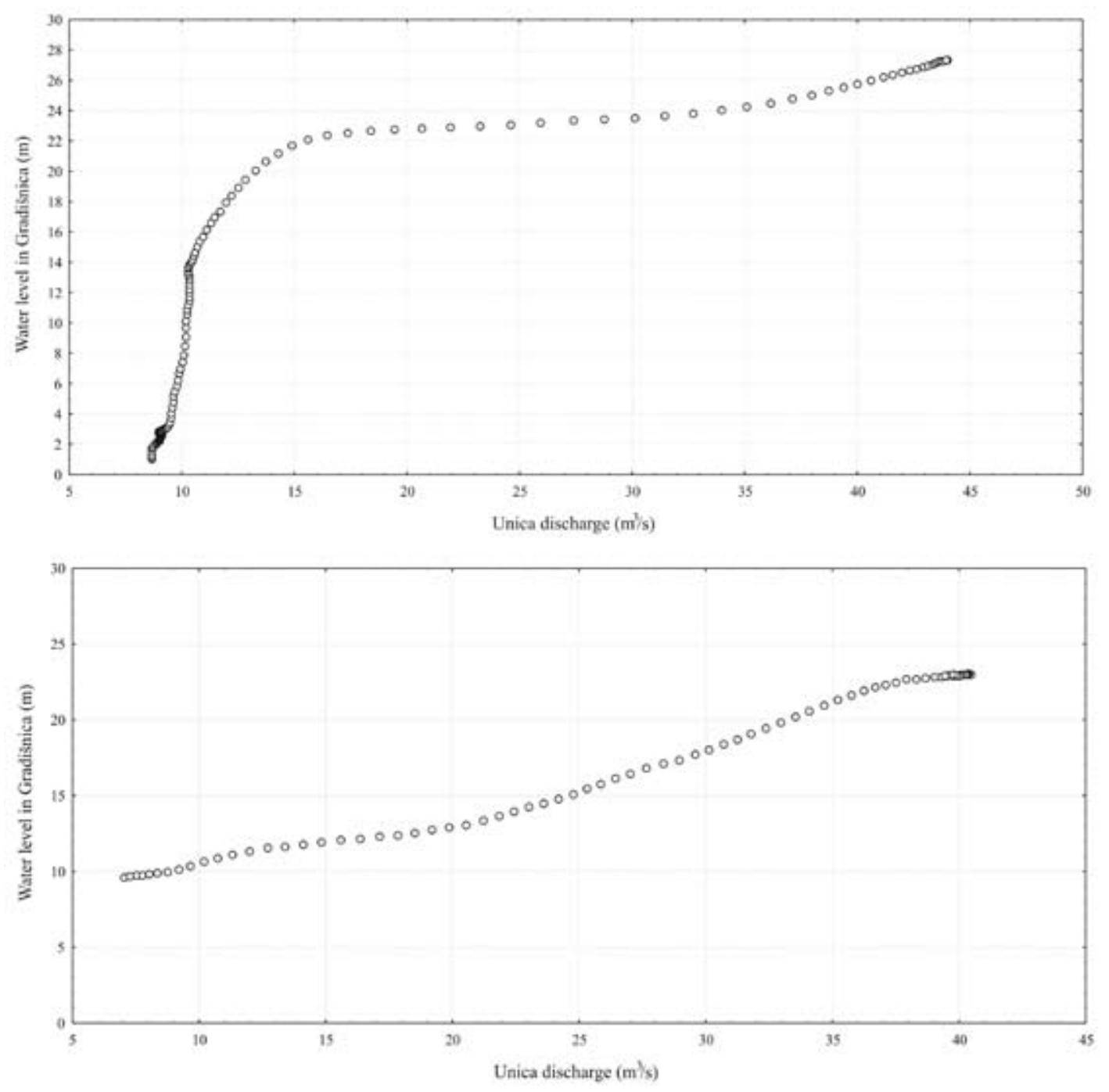

Fig. 9. Rapid event in Gradišnica (above), Slow event in Gradišnica (below).

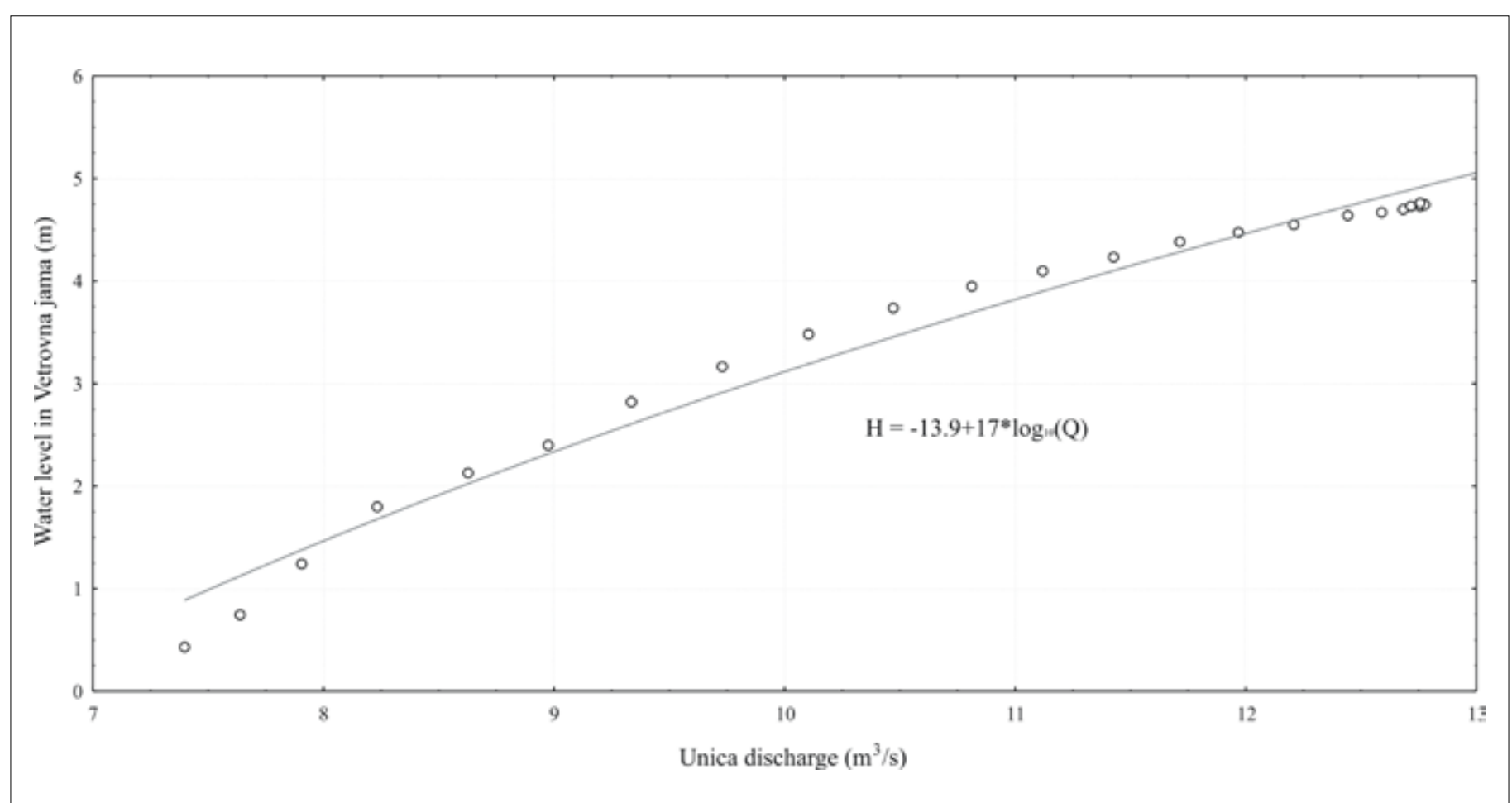

Fig. 10. Relation between water level in Vetrovna jama (H) and Unica River discharge (Q) during November 2006 flood pulse. Equation represents best fit. 
Tab. 1: Hydraulic gradients

\begin{tabular}{|c|c|c|c|c|c|c|c|}
\hline & $\begin{array}{c}\text { Planinsko } \\
\text { polje }\end{array}$ & $\rightarrow$ & Najdena jama & $\rightarrow$ & Gradišnica & & Gašpinova jama \\
\hline Hydraulic gradient (\%) & & 8 & & 1 & & 0.1 & \\
\hline
\end{tabular}

\begin{tabular}{|c|c|c|c|}
\hline & Planinsko polje & $\rightarrow$ & Vetrovna jama \\
\hline Hydraulic gradient (\%) & & 1 & \\
\hline
\end{tabular}

\begin{tabular}{|c|c|c|c|}
\hline & Cerkniško polje & $\rightarrow$ & Vetrovna jama \\
\hline Hydraulic gradient (\%) & & 1 & \\
\hline
\end{tabular}

smaller proportion than slower flood pulse. Therefore more water reached swallow holes in the northern polje margin, which feeds Najdena jama directly, and consequently also the caves Gradišnica and Gašpinova jama.

\section{Hydrodynamic characteristics in Vetrovna jama}

Vetrovna jama is considered separately. The input to Vetrovna jama is the most complex of all four discussed caves. It is undoubtedly connected with some swallow holes at the eastern margin of Planinsko polje and with some swallow holes at the bottom of Cerknica Lake, as was determined by our measurements.

Connection between the Unica River swallow holes and Vetrovna jama is proven with the flood pulse of November 2006 (Fig. 6a). Rain, after a long dry period, caused an increase of Unica discharge. But there was not enough precipitation to fill the periodically dry Cerkniško polje, which is fed by streams. A small flood pulse caused increasing Unica River discharge from an extremely low $3 \mathrm{~m}^{3} / \mathrm{s}$ to $13 \mathrm{~m}^{3} / \mathrm{s}$. The water level in Najdena jama did not increase after the flood pulse, therefore we conclude that the majority of water flow sank underground on the eastern polje margin. The relation between discharge of the surface Unica and the water level in Vetrovna jama is significant. On the other hand, there is no relation between Unica River discharge and water level in Najdena jama. According to these relations a direct water connection between underground Unica River and Vetrovna jama can be proven. However, relations are very problematic in the period of seasonal existence of the karst lake in Cerkniško polje. During that period, waters from at least two major different sources are mixing in Vetrovna jama.

Monitoring of the fluctuation of Cerknica Lake was not established in the study period, thereforedirectcomparison between Cerknica Lake levels and underground water in Vetrovna jama has not been possible. Anyway the behaviour of Cerknica Lake oscillation is known, and it can be said that the water level oscillations in Vetrovna jama, after reaching some maximal plateau during flood pulses in December 2006 and January 2007, correspond to the behavior of lake oscillations.

Fig.10 presents hydraulic conditions during the November (2006) flood pulse in Vetrovna jama. Input was from the Unica River only at that time, as was already mentioned. The water level rose four meters in nine hours. But the capacity of restrictions to transmit water is relative low, as also the Unica River maximum discharge $\left(13 \mathrm{~m}^{3} / \mathrm{s}\right)$ was far from its mean discharge $(21$ $\left.\mathrm{m}^{3} / \mathrm{s}\right)$.

\section{CASE STUDY 2: HYDRODYNAMICS OF UNDERGROUND WATER FLOW BETWEEN BLOŠKO POLJE AND CERKNIŠKO POLJE}

\section{Introduction}

Križna jama (Križna Cave) and Križna jama 2 (Križna Cave 2) with more than $9.688 \mathrm{~m}$ horizontal epiphreatic water passages gives us excellent opportunity to follow one part of the main underground water courses between Bloško polje (Bloke plateau) and Cerkniško polje (Cerknica polje). Access to water of Križna jama is known for more than 5.000 years, while the continuation of underground water course toward Cerkniško polje was discovered through Križna jama 2 in 1991, when cavers made a breakthrough through the breakdown slope of collapse doline Grdi dol, which separates the two caves. The connection between caves has not been done by divers as the connection siphons reach a depth of $70 \mathrm{~m}$ in Križna jama (Kittlova brezna) and over $70 \mathrm{~m}$ in Križna jama 2 (Pritočno jezero). Due to fragile flowstone dams, Križna jama 2 is on the list of 5 highly protected caves in Slovenia and accessible only with special permission by Ministry of the Environment and Spatial planning.

The purpose of our research is to characterize hydrogeological characteristics of the aquifer between Bloško polje and Cerkniško polje, and to evaluate the aquifer's hydrodynamic settings with respect to variety and intensity of corrosion $v s$. flowstone depositional processes within a cave system.

\section{Methodology}

At Prvo jezero (see Fig. 14) in Križna jama a Gealog $S$ (Logotronic) data logger was used for defining temporal variations of water level, temperature and specific electrical conductivity (SEP). Due to the rapid response of stream discharge in Križna jama to precipitation, the sample interval was set to 5 minutes. We also used a Multiline meter (WTW) at 59 different locations inside the caves for defining spatial variability of temperature, conductivity and $\mathrm{pH}$. Measurements of flowstone deposition $v s$. corrosion rates were done with standard weightloss limestone tablets (Gams, 1985) and with geomorphological mapping. With such an approach we tried to attain a better understanding of hydrogeology, underground hydrodynamics, and to answer the question, how is hydrodynamics reflected in changing corrosion and flowstone deposition rates. Over longer periods of time we should also 


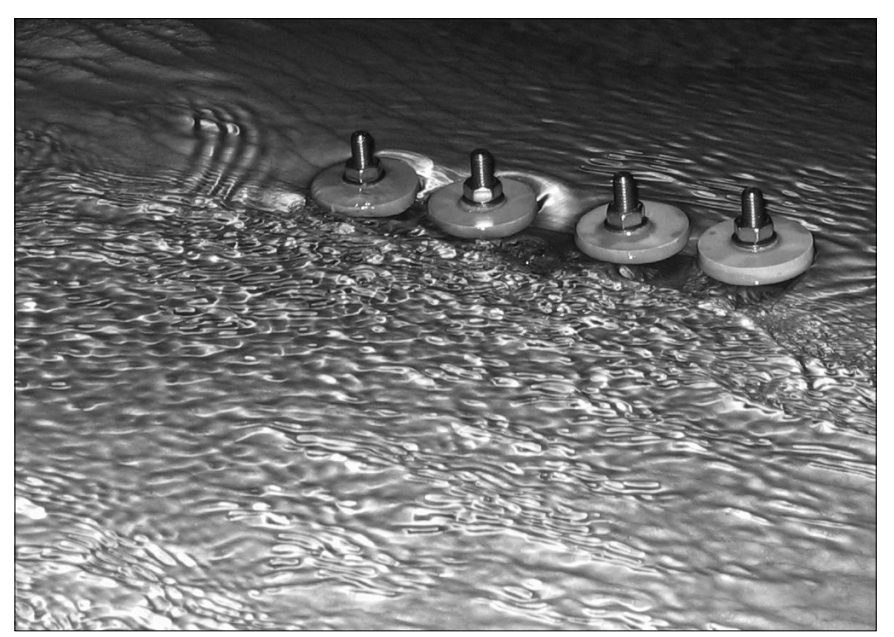

Fig. 11. Measuring of flowstone deposition with standard limestone tablets (Photo: Mitja Prelovšek). take into consideration the opposite relationship where changes of corrosion or deposition influence conductivity of the cave system.

\section{Hydrogeological and hydrodynamic settings between Bloško polje and Cerkniško polje}

The aquifer between Bloško polje and Cerkniško polje is composed of 4 lithostratigraphical units (Osnovna geološka karta Postojna, 1963; Osnovna geološka karta Ribnica, 1965):

- upper Triassic dolomite $\left(\mathrm{T}_{3}{ }^{2+3}\right)$,

- lower Jurassic dolomite $\left(\mathrm{J}_{1}\right)$,

- lower-middle Jurassic limestone with thin lenses of dolomite $\left(\mathrm{J}_{1,2}\right)$ and

- upper Jurassic dolomites $\left(\mathrm{J}_{3}\right)$.

All the units are generally inclined 20-40 degrees toward southwest. Without any significant tectonic

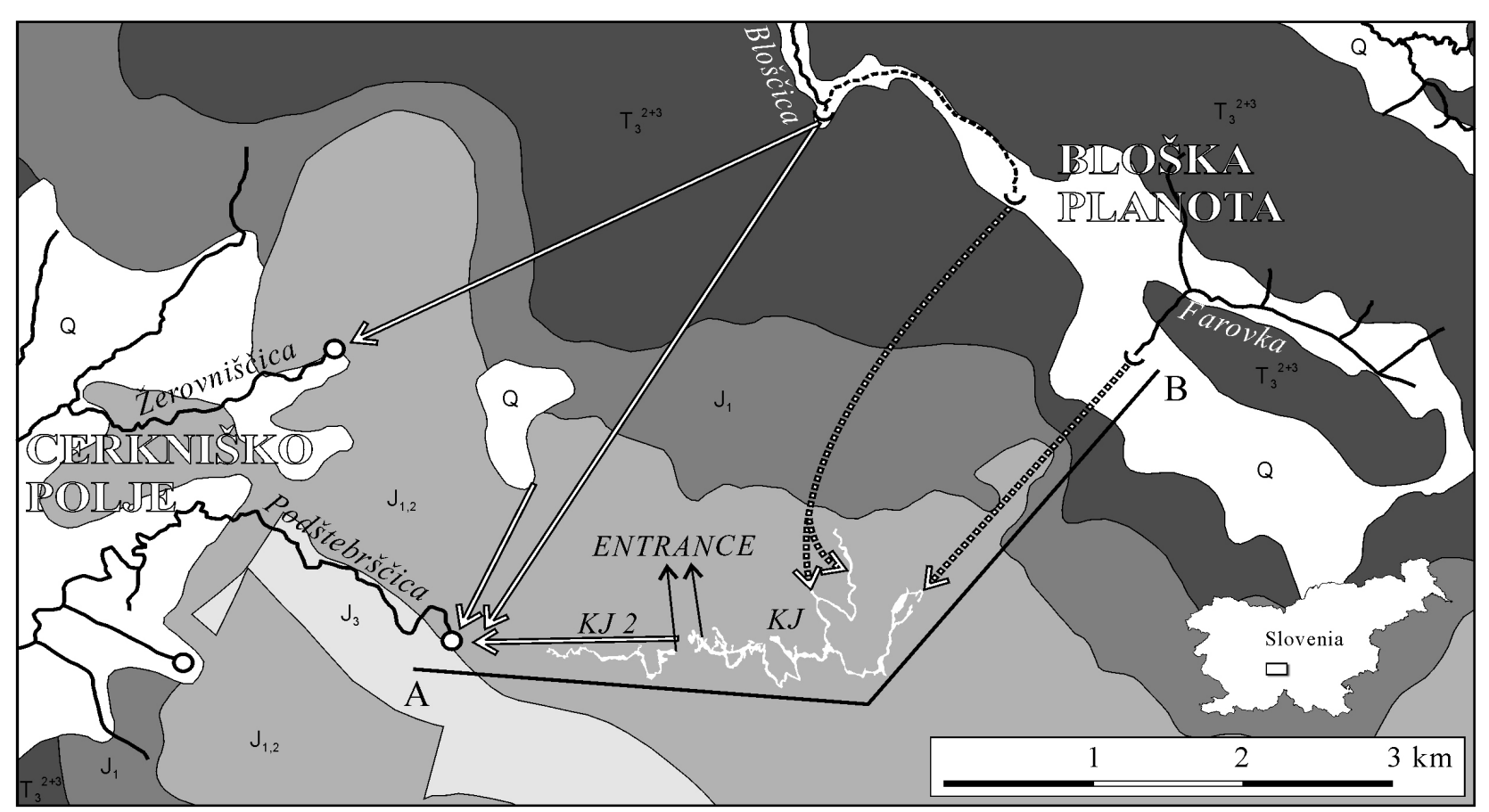

elevation $\mathrm{A}$

B

(m a.s.1.)

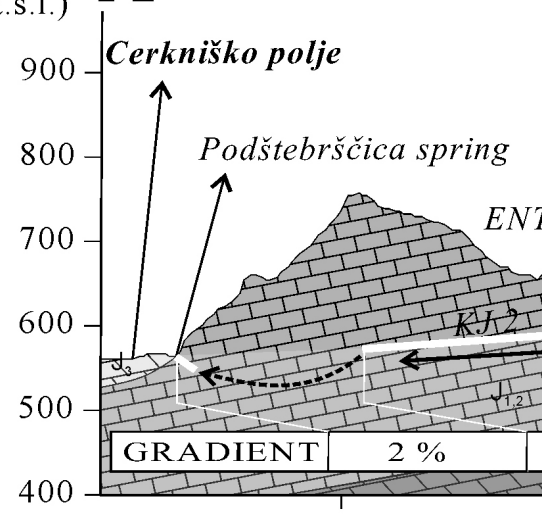

1

2

limestone

important spring

स्येdomite

$r$ important ponor

12 traced water connections

$\longleftrightarrow_{6}^{\circ \infty}$ supposed water conection

«.- unexplored water passages

Geological settings modified from Osnovna geološka karta Postojna \& Ribnica (1963 \& 1965).

Fig. 12. Hydrogeological map with cross-section between Bloško polje and Cerkniško polje with caves Križna jama (KJ) and Križna jama 2 (KJ 2). 
displacement, they show a quite undisturbed chronostratigraphical sequence from the oldest rocks at the northeast to the youngest at southwest. The area lies a few kilometers northeast of the Idria strike-slip fault, and because of this the rocks are well fractured especially in N-S direction (Gospodarič, 1974). Some of these fractures are well expressed in observed cave passage directions (Fig. 12). Since the caves Križna jama and Križna jama 2 cover nearly half a waterway between Bloško polje and Cerkniško polje, and cross different litostratigraphic units, we have a quite good insight in the underground flow conditions (Fig. 12). Underground flow is composed of alternating free surface and pressurized flow.

The first water tracing experiment in the study area was done in 1939 and proved the supposed connection between Bloščica ponor (717 $\mathrm{m}$ a.s.1.) and the springs of Žerovniščica (564 $\mathrm{m}$ a.s.1.) and Podštebrščica (563 $\mathrm{m}$ a.s.1.). The passages at this underground connection are known only from Žerovniščica spring as the cave Veselova jama in distance of $420 \mathrm{~m}$. In 1969 Novak $(1966,1969,1990)$ proved the connection between Križna jama and Podštebrščica spring. At that time Križna jama 2 was not discovered yet so we do not know if the dye appeared in the cave. Dye was injected at middle to high water level (cca. 140 1/s) at Ponor (Križna jama; see Fig.10), after 1.5 $\mathrm{h}$ visually detected in Dežmanov rov (Križna jama), after 35 hours in northern Kittlovo brezno (Križna jama), and finally after $130 \mathrm{~h}$ in Podštebrščica spring. The tracing experiment showed fast water movement in pressurized phreatic flow between the Ponor and Dežmanov rov $(5.6 \mathrm{~cm} / \mathrm{s})$, probably because of the narrow phreatic conduit, while the connection between Dežmanov rov, Kittlovo brezno and Podštebrščica spring indicate much slower velocities of water $(0.4-$ $0.9 \mathrm{~cm} / \mathrm{s})$. In 1969 Križna jama 2 was not known yet and we do not know how much time the water body needs to pass the siphon between caves Križna jama and Križna jama 2. But the subsequent explorations of Križna jama 2 showed relatively fast water movement within the cave because of the smaller wetted area of the water course. Since the water of Križna jama enters fully flooded phreatic channel between Križna jama and Križna jama 2 with larger wetted area of water course, much lower velocities appears. We can conclude that higher velocities are characteristic for epiphreatic or shallow phreatic passages and contrary slower velocities for deeper phreatic passages. Water connection between Farovka ponor and Pisani rov (Križna jama) is supposed to be wide and near water table because of polystyrene findings in Pisani rov. Easily floating polystyrene was deposited at Farovka ponor.

In some way it is surprising that the lowest gradient between Bloško polje and Cerkniško polje is developed in a deep phreatic loop between the caves Križna jama and Križna jama 2. The altitudes of connection sumps between caves Križna jama and Križna jama 2 are nearly the same and this means that flow of water here is not restricted from deep phreatic looping or from the side of the $150 \mathrm{~m}$ wide and $40 \mathrm{~m}$ deep collapse doline Grdi dol, which separates the surface connection of the two caves. Hydraulic gradient in Triassic dolomite $\left(\mathrm{T}_{3}{ }^{2+3}\right)$ is slightly higher than in limestones but not significantly if we compare it with the gradient in Križna jama 2, which lies in Jurassic limestones $\left(\mathrm{J}_{1,2}\right)$.

Although the north-eastern part of Križna jama receives water from Jurassic and Triassic dolomites (which are usually recognized as less permeable for water) the response to rainfall can be very fast and strong. Rapid response of underground water level to precipitation is characteristic for all the carbonates: Triassic dolomites, Jurassic dolomites and Jurassic limestones. On 25 $5^{\text {th }}$ March 2007 a moderate storm raised water in Križna jama (Prvo jezero) by $50 \mathrm{~cm}$ in 11 hours with the highest rise up to $9 \mathrm{~cm} /$ $\mathrm{h}$ (measurements were taken at a $4 \mathrm{~m}$ wide stream with free surface). Similar stage increases were also observed on $7^{\text {th }}$ June 2007 and on $4^{\text {th }}$ July 2007 (Fig. 15). In known passages the piezometric level annually fluctuates up to $2 \mathrm{~m}$. In water conditions that appear once every ten years water can rise in the lower parts of Križna jama up to $5 \mathrm{~m}$. Those data confirm the idea of wide and well organized passages in both types of carbonate rocks without any significant restrictions.

Despitethesewelldeveloped passagesindolomitesand limestones, slower dissolution of dolomite is observed at both micro and macro scales. Lenses of dolomite jut out from the scalloped walls. Additionally, some other micro features, that are numerous in limestones (wall notches, dissolutional pockets, decantation runnels), are absent on the surfaces of dolomites or dolomite lenses within limestones. Geomorphological mapping of the northern Blata branch (Križna jama) showed also that the passage narrows gradually from $20 \mathrm{~m}$ to $10 \mathrm{~m}$ when it crosses the stratigraphic boundary between Jurassic limestone and dolomite. Even so, narrowing of the passages in dolomite of Križna jama does not function as a restriction.

\section{Influence of the corrosion-deposition process on hydraulic properties of the cave system}

Since the underground system between Bloško polje and Cerkniško polje represents an easy accessible and well documented case of a complex cave system (pressurized-free flow, many tributaries to main water course, changes in saturation index along water course), we should emphasize the relations between corrosion-depositional processes and spatial and temporal hydrodynamics. Holcene changes in cave geomorphology in already described case study 1 (underground system Planinsko poljeLjubljanica springs) are of minor importance, since the dissolution rates are relatively small (up to $0.05 \mathrm{~mm} / \mathrm{a}$ in Najdena jama; Prelovšek, unpublished data) in comparison to discharges of underground water flow (Unica River has up to 80 $\left.\mathrm{m}^{3} / \mathrm{s}\right)$. Holocene changes in morphology are more important in Bloško polje-Cerkniško polje cave system, where discharges are rarely more than $10 \mathrm{~m}^{3} / \mathrm{s}$ and corrosion or flowstone deposition processes are more intensive. 


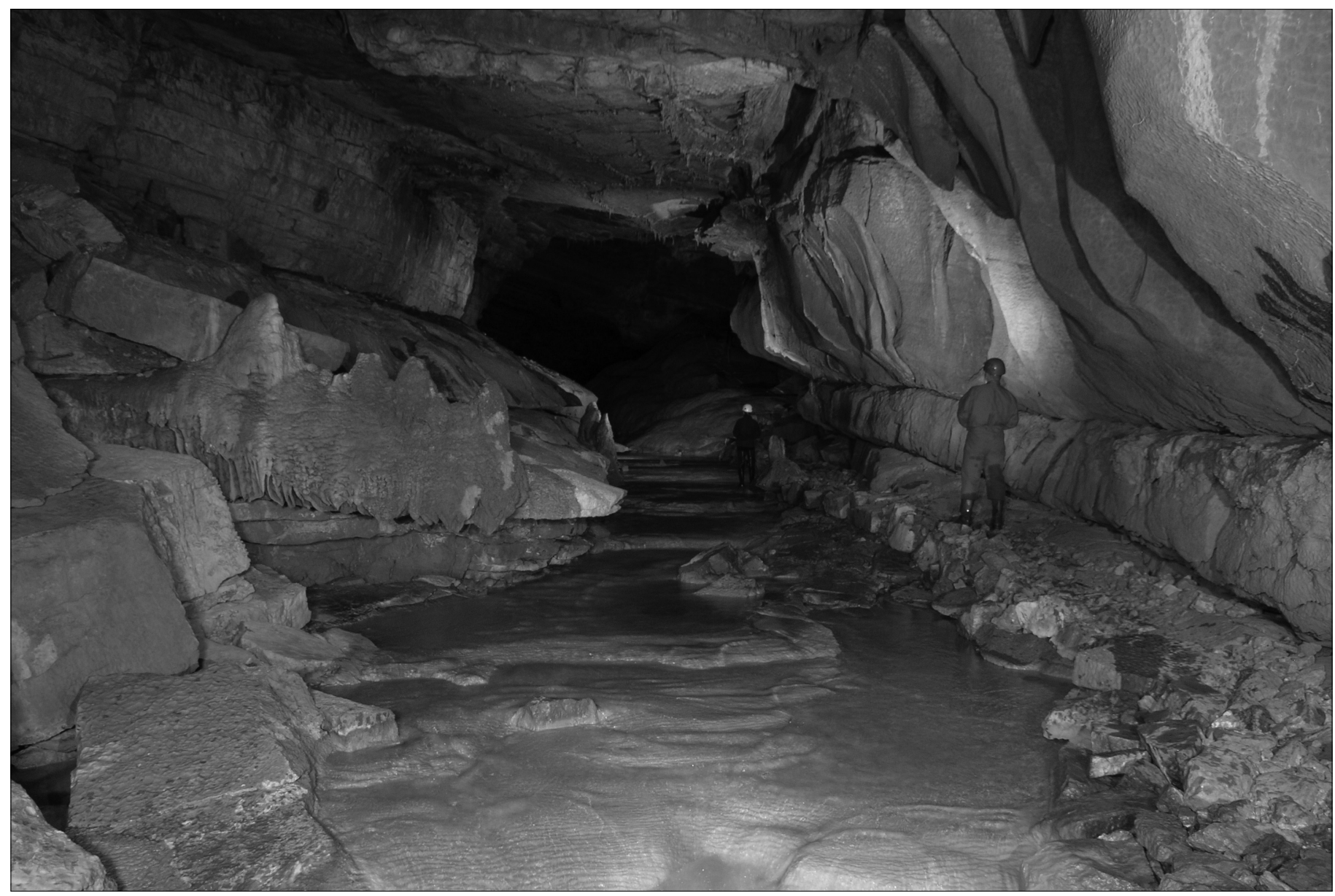

Fig. 13. Typical epiphreatic passage in Križna jama with flowstone deposition on the floor (Photo: Alojz Troha).

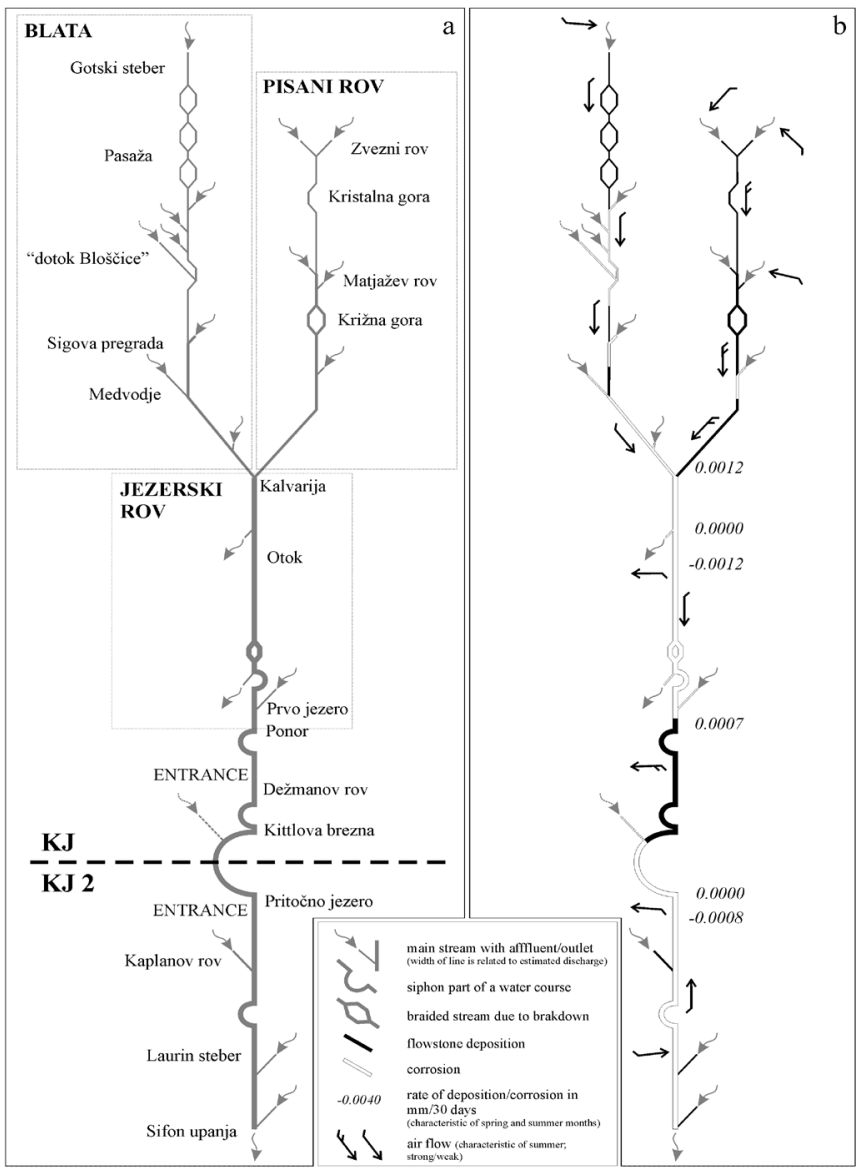

Fig. 14. (a) Underground hydrological network with (b) flowstone deposition/corrosion processes in Križna jama $(\mathrm{KJ})$ and Križna jama 2 (KJ 2; summer conditions at low-middle water level).
Microerosion measurements made by Mihevc (1997) in years 1994, 1997 and 2007 show that flowstone deposition at the outflow from Prvo jezero (Križna jama) amount 0.08 $\mathrm{mm} / \mathrm{a}$. In the last 12,000 years, during which the climate and corrosion-depositional processes have been quite constant, such a deposition rate would produce about a $1 \mathrm{~m}$ high flowstone dam. Such a thickness of flowstone deposit fits very well with morphological observations. Flowstone deposition areas at Ponor, between Prvo jezero ( $1^{\text {st }}$ lake) and $2^{\text {nd }}$ lake, Kalvarija and Pasaža in Križna jama narrow active channels and also cause the transition from free surface flow to pressurized flow, especially at high waters. Active flowstone deposition from vadose water in the Blata passage near Kalvarija (Križna jama) also obstructs water outflow from Blata and causes a rise of water level of more than 3 meters at high discharge. The highest observed corrosion rate in the underground system is about $-0.01 \mathrm{~mm} / \mathrm{a}$ in Križna jama 2. Since this produces about $0.24 \mathrm{~m}$ enlargement of phreatic passages over the course of the Holocene, it can be considered along with flowstone deposition as an important factor for changes in recent hydrodynamics, at least in the caves Križna jama and Križna jama 2.

The transitions between corrosion and flowstone deposition in the Bloško polje-Cerkniško polje underground system are numerous and evident from morphology and water chemistry. In some parts of the underground system karst water seems to be oversaturated with respect to calcite (SI positive), and consequently flowstone is deposited. But in other areas SI seems to be negative with corrosion (see Fig. 14). Such a situation encouraged 


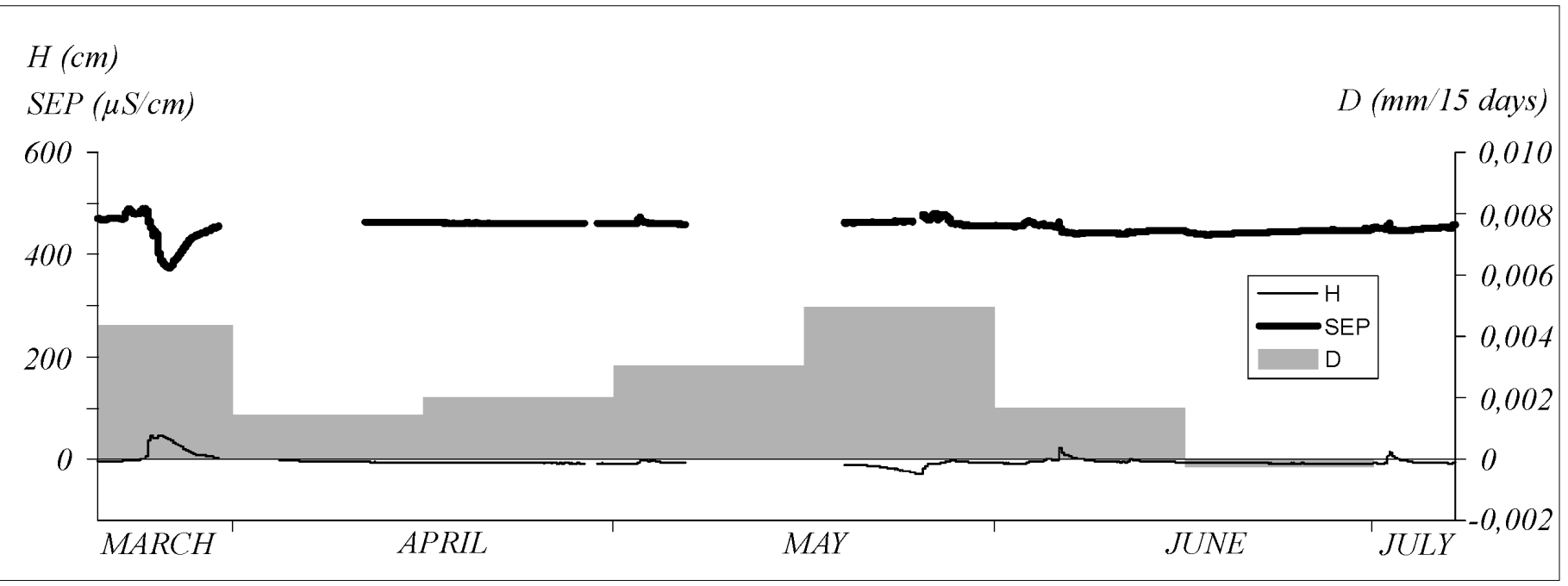

Fig. 15. Time series of specific electrical conductivity (SEP), height of water $(H)$ and corrosion/flowstone deposition rates (D) at Prvo jezero of Križna jama (21.3.2007-10.7.2007). Heights of water above $100 \mathrm{~cm}$ have the recurred period about 0.5 year.

us to measure flowstone deposition and corrosion rates with microerosion meter (MEM) together with more precise weight-loss limestone tablets. Limestone tablets were placed in a longitudinal section at 3 places from the lower end of Pisani rov to the Prvo jezero (Križna jama) and at 2 places in Pritočno jezero (Križna jama 2). They were replaced every 30 days from $13^{\text {th }}$ January 2007 to $15^{\text {th }}$ June 2007. Average monthly values in spring-summer season show flowstone deposition only at the lower end of Pisani rov and at Prvo jezero, while at other measurement points results show equilibrium or slight corrosion. Rate of processes is low but out of the error of measurement and quite stagnant over time.

Since the direct measurements of geomorphic process with limestone tablets or microerosion meter are quite time consuming, we extended measurements with geomorphological mapping and physico-chemical measurements of $\mathrm{pH}$, specific conductivity (SEP) and temperature (T) at 59 locations in Križna jama and Križna jama 2. The measurements were done at low-middle flow stage and could be different at high waters.

Water that originates from Bloško polje at the end of Pisani rov and Blata, as well as several tributaries to this main stream, is transported through siphons or at least poorly aerated passages. For this reason water is rich with $\mathrm{CO}_{2}$ and has consequently significantly lower $\mathrm{pH}$ (7.1-7.8) and in contrast with higher SEP $(420-490 \mu \mathrm{S} / \mathrm{cm})$ they are corrosive. When such corrosive water reaches a well aerated main passage it starts to loose $\mathrm{CO}_{2}$. This phenomenon is common at the change of boundary conditions (Dreybrodt, 2000) and in Križna jama is well observed with raised $\mathrm{pH}$ value. If $\mathrm{pH}$ and SEP (in this case SEP represents mainly carbonates) are significantly high, water is transformed from undersaturated to saturated, and calcite starts to precipitate from water. When that tributary mixes with the main stream, $\mathrm{pH}$ of the main stream consequently falls down after junction. As a consequence tributary turns main stream from deposition of flowstone to corrosion. It normally takes some tens of meters in Blata and Pisani rov that the water aerates enough again for flowstone deposition. A change from flowstone deposition to corrosion is well observed with flowstone dams vanishing below Pasaža, in Sigova pregrada, Medvodje, below Križna gora, in Kalvarija and also between Križna jama and Križna jama 2 (Fig. 14). Such a situation in Križna jama shows growth of phreatic passages and consequent reduction of hydraulic gradient on one side, and filling the main aerated passage with flowstone with increased hydraulic gradient on the other side, with actually the same water body. The conditions are not so different at high stage as was observed in many caves around the world (for example McFail's cave; Palmer, 2007). In Križna jama the SI falls from about 0.6 at low waters only to -0.1 at high waters and corrosion can not be related to high waters. In the case of measurements between the $21^{\text {st }}$ of March 2007 and $10^{\text {th }}$ of July 2007, we even observed, surprisingly, a negative correlation between corrosion and height of water (Fig. 15).

\section{CONCLUSIONS}

The observed hydrodynamics in the area between Planinsko polje and Ljubljansko barje confirm some hypotheses of water connections between the monitored caves. Flood pulses were well followed from Unica River through the caves Najdena jama, Gradišnica and Gašpinova jama. Vetrovna jama belongs to another system, where beside Unica distribution, we recognized also some water contribution from Cerknica Lake. From the Unica ponors to Gradišnica underground flow is similar to turbulent flow between connected reservoirs. In the continuation, the hydraulic gradient is lowered and reaches the value $0.1 \%$ between Gradišnica and Gašpinova jama (Tab. 1). Because of the low hydraulic gradient, underground flow between those two caves should be slow.

Similar downstream lowering of gradients was also observed between Bloško polje and Cerkniško polje. Breaking of restrictions, reducing the friction and consequent lowering of hydraulic gradient can be possible only with enlargement of water channels by corrosion, abrasion, or redeposition of allogenic material. Intensive corrosion is well known in the upper part of the Bloško polje-Cerkniško polje cave system where non-aerated conditions (probably in the mixed shallow phreatic to epiphreatic zone) enhance dissolution of dolomite.

At high water stages the 2 studied underground systems differ significantly. The restrictions in the underground 
system between Planinsko polje and Ljubljanica springs are significantly higher than those between Bloško polje and Cerkniško polje. In the known epiphreatic and phreatic passages of the caves Križna jama and Križna jama 2, water can rise several meters during high discharge, but never more than $10 \mathrm{~m}$. Phreatic and epiphreatic channels are so wide that discharges up to $10 \mathrm{~m}^{3} / \mathrm{s}$ are transferred through the limestone-dolomite aquifer without any significant flooding. Since the discharges in case study 1 are significantly higher and restriction more pronounced, flooding of more than $50 \mathrm{~m}$ can occur.

\section{ACKNOWLEDGEMENTS}

The authors would like to thank Mr. Bojan Volk and other members of Jamarsko društvo Logatec (Speleo club Logatec) for help and escort in the caves Vetrovna jama and Gašpinova jama. We also appreciate the help of Alojz Troha, who has made many helpful halfscientific observations in Križna jama. Finally, thanks to Ira D. Sasowsky for grammatical and English language editing.

\section{REFERENCES}

Bonacci O., 1987 - Karst hydrology, with special reference to the Dinaric karst. Springer, Verlag Berlin Heidelberg, $184 \mathrm{pp}$.

Campbell C.W. \& Sullivan S.M., 2002 - Simulating timevarying cave flow and water levels using the Storm Water Management Model. Engineering Geology, 65 (2-3): 133-139.

Chow V.T., 1988 - Open-channel hydraulics. McGraw-Hill, New York, 680 pp.

Dingman S.L., 2002 - Physical hydrology. Prentice Hall, Upper Saddle River, N.J., 646 pp.

Dreybrodt W., 2000 - Equilibrium Chemistry of Karst Water in Limestone Terranes. In: Klimchouk A., Ford D. C., Palmer A. N. \& Dreybrodt W. (Eds.), Speleogenesis. Evolution of karst aquifers. Huntsville: National Speleological Society: 126-135.

Gabrovšek F. \& Peric B., 2006 - Monitoring of the flood pulses in the epiphreatic zone of karst aquifers: The case of Reka river system, Karst plateau, SW Slovenia. Acta carsologica, 35 (1): 35-45.

Gale S.J., 1984 - The hydraulics of conduit flow in carbonate aquifers. Journal of Hydrology, 70 (1-4): 309-327.

Gams I., 1985 - Mednarodne primerjalne meritue pouršinske korozije s pomočjo standardnih apneniških tablet (International comparative measurements of surface solution by means of standard limestone tablets). Razprave IV. reda SAZU: 361-388. (Slovenian with English abstract).

Gioia G. \& Bombardelli F.A., 2002 - Scaling and similarity in rough channel flow. hysical review letters, 88 (1): 14501.

Gospodarič R., 1974 - Fluvialni sedimenti v Križni jami (Fluvial sediments in Križna jama). Acta carsologica, 4: 325-366. (Slovenian and English).

Gospodarič R. \& Habič P. (editors), 1976 - Underground water tracing - Investigations in Slovenia 1972-1975. Ljubljana, $309 \mathrm{pp}$.
Halihan T. \& Wicks C.M., 1998 - Modeling of storm responses in conduit flow aquifers with reservoirs. Journal of Hydrology, 208 (1-2): 82-91.

Hauns M., Jeannin P.-Y. \& Hermann F., 1998 - Tracer transport in karst underground rivers: tailing effect from channel geometry. Bulletin d'Hydrogeologie, 16: $123-142$.

Jeannin P., 2001 - Modeling flow in phreatic and epiphreatic karst conduits in the Holloch cave (Muotatal, Switzerland). Water Resources Research, 37 (2): 191-200.

Kogovšek J., 2004 - Fizikalni kemične značilnosti voda $v$ zaledju Malenščice - Slovenija (Physico-chemical properties of waters in the Malenščica recharge area-Slovenia). Acta carsologica, 33 (1): 143-157.

Larock B.E., Jeppson R.W. \& Watters G.Z., 2000 - Hydraulics of pipeline systems. CRC Press, Boca Raton, FL, 537 pp.

Mihevc A., 1997 - Meritve hitrosti rasti sige na pregradah $v$ Križni jami (Flowstone deposition rates at flowstone dams in Križna jama). Naše jame, 39: 110-115. (Slovenian).

Novak D., 1966 - Poročilo o barvanju v Križni jami 1965 (Report on water tracing in Križna jama 1965). Naše jame, 8 (1-2): 89. (Slovenian).

Novak D., 1969 - O barvanju potoka v Križni jami (About water tracing of underground stream in Križna jama). Geografski vestnik, 41: 75-79. (Slovenian).

Novak D., 1990 - Novejša sledenja kraških voda v Sloveniji po letu 1965 (Newer water tracing of karst waters in Slovenia after 1965). Geologija, 33: 461-478. (Slovenian).

Osnouna geološka karta Postojna (Elementary geological mapPostojna), 1963. Ljubljana: Geološki zavod Ljubljana.

Osnouna geološka karta Ribnica (Elementary geological mapRibnica), 1963. Ljubljana: Geološki zavod Ljubljana.

Palmer A. N., 2007 - Variation in rates of karst processes. Acta carsologica, 36 (1): 15-24.

Peterson E. \& Wicks C., 2005 - Fluid and solid transport from a conduit to the matrix in carbonate aquifer systems. Mathematical geology, 37 (8): 851-867.

Peterson E. \& Wicks C., 2006 - Assessing the importance of conduit geometry and physical parameters in karst systems using the storm water management model (SWMM). Journal of Hydrology, 329 (1-2): 294-305.

Pleničar M. et al., 1970 - Tolmač osnoune geološke karte1:100.000 (Commentary of Elementary geological map 1:100.000). Beograd. (Slovenian)

Rossman L.A., 2007 - Storm water management model user's manual: Version 5.O. U.S. Environmental Protection Agency, 255 pp..

Rozos E. \& Koutsoyiannis D., 2006 - A multicell karstic aquifer model with alternative flow equations. Journal of Hydrology, 325 (1-4): 340-355.

Springer G., 2004 - A pipe-based, first approach to modeling closed conduit flow in caves. Journal of Hydrology, 289 (1-4): 178-189.

Šušteršič F., 2000 - Speleogenesis in the Ljubljanica River Drainage Basin, Slovenia. In: Klimchouk A.B., Ford, D.C., Palmer A.N. \& Dreybrodt W. (Eds.) - Speleogenesis, Evolution of Karst Aquifers. Hunstville: National Speleological Society: 397-406.

Šušteršič F., 1982 - Morfologija in hidrologija Najdene jame (Morphologic and geologic situation of caves at the Planina polje ponor boundary). Acta carsologica, 10: 127-155 